6. Дела о расторжении брака в Украинской ССР. Социалистическая законность. 1948. Сентябрь. № 9. С. 35-36.

7. Сусло Д.С. Недостатки практики судов Украинской ССР по делам о расторжении брака. Социалистическая законность. 1947. Апрель. № 4. С. 26-27.

8. Хохлов Н. Недостатки в работе некоторых судов по делам о расторжении брака. Социалистическая законность. 1949. Ноябрь. № 11. C. 15-19.

DOI https://doi.org/10.30525/978-9934-26-074-2-4

\title{
ІМПЕРСЬКА БІЛЬШОВИЦЬКА ПОЛТТИКА ГЕНОЦИДУ УКРАЇНСЬКОГО НАРОДУ ЧЕРЕЗ ОРГАНІЗАЦІЮ ШТУЧНИХ ГОЛОДОМОРІВ
}

\author{
Дурнов С. С. \\ доктор юридичних наук, професор, \\ начальник відділу \\ Департаменту персоналу Міністерства внутрішніх справ Украӥни \\ м. Київ, Україна \\ Сокур Ю. В. \\ кандидат юридичних наук, доцент, \\ дочент кафедри історії держави та права \\ Національної академії внутрішніх справ \\ м. Київ, Украӥна \\ Щербатюк В. М. \\ доктор історичних наук, професор, \\ професор кафедри історії держави та права \\ Національної академії внутрішніх справ \\ м. Київ, Украӥна
}

Слід зазначити, що для радянських дослідників і вчених тема Голодомору була закритою. Офіційна ідеологія і пропагандистська машина комуністичної партії стверджувала, що такого явища взагалі не існувало. Понад півстоліття трагедія Голодомору в Україні 1932 - 1933 pp. перебувала поза увагою світової громадськості. Лише у листопаді 1998 р. у 65-річчя найстрашнішого геноциду українського народу вперше 
в Україні було широко вшановано мільйони жертв. Того ж року вийшов Указ Президента України Л. Кучми, згідно з яким в останню суботу листопада щороку вшановуватимуться жертви Голодомору. Цей день став Днем пам'яті жертв Голодомору.

Ще 1918 р. на території України військовою силою була запроваджена продрозкладка - система примусової заготівлі сільськогосподарських продуктів у 1918-1921рp. На VIII партійному з'їзді, що відбувся у березні 1919 р. вирішено вжити заходів по організації землеробства, серед яких пролунала пропозиція створення колективних господарств - сільськогосподарських комун та артілей. 3 другої половини 1920-х років керівники більшовицької започатковують індустріалізацію та колективізацію. Водночас була заборонена вільна торгівля продуктами.

Запровадження насильницької продрозкладки викликало незадоволення селян, які вдалися до активного збройного спротиву, захищаючи власні майно і врожай [1]. Однак насильницька політика більшовиків в українському селі [2] призвела до глибокої економічної та політичної кризи в Україні, яку більшовики намагалися подати як «продовольчі труднощі» [3, с. 151]. У зв'язку з цим більшовики посилили так звану продовольчу роботу - фактично насильницьке відбирання зерна, інших продуктів та навіть особистого майна селян. Для цього в Україну були послані тисячі робітників-залізничників, російських селян iз північних теренів Росії, де населення перебувало на межі голоду. Цей прийшлий в Україну контингент був зацікавлений у такій роботі, адже, як писав В. Ленін мав «особо ясно осознавать и чувствовать несправедливость обжорства крестьян на Украине» [4, 67]. У таких обставинах у 1921 - 1923 pp. у боротьбі з українським селянством більшовики вперше застосували голод. Згодом, визнавши цей метод боротьби дієвим, у повній мірі його було застосовано у 1932-1933 pр. Більше того, намагаючись приховати трагічні події, що відбувалися в Україні від світової громадськості, кордони України було наказано оточити військами, щоб не дати голодуючим роз'їхатись по світу.

Штучний характер Голодоморів підтверджується політикою, яку проводили більшовики в Україні на чолі з В. Леніним у 1918-1920-х роках, а у 1930-1940-х роках - на чолі із Й. Сталіним. Підгрунтям проведення геноциду стали урядові вказівки та вироблені на їх основі партійні документи. Так, у 1921 р. В. Ленін письмово наказав М. Фрунзе, що головне завдання на той час для всієї Радянської влади - зібрати 3 України 200-300 млн пудів хліба, що було тоді для більшовиків питанням життя і смерті... [5, с. 300]. Ще раніше Л. Троцький, виступаючи на таємній інструктивній нараді перед політкомісарами, які 
виїжджали в Україну, закликав повернути іiі імперській Росії, яка з 1917 р. вела визвольну боротьбу за свою державність, адже, як зазначалось, без українського вугілля, заліза, руди, хліба, солі і Чорного моря Росія існувати не може, вона задихнеться і з нею - радянська влада... Для партійних і радянських чиновників вводилась брехлива інструкція, суть якої зводилась пояснювати в українському суспільстві, що хліб візьмуть тільки у куркулів і не для Росії, а для бідних українських селян, робітників і Червоної армії, яка вигнала Денікіна 3 України [6, с. 15].

Організація штучних Голодоморів 1920 - 1930-х років в Україні була спричинена імперською політикою більшовиків, які, здобувши владу, перестали агітувати за право націй на самовизначення і виокремлення їх у незалежні держави. Перейнявши естафету у царської влади, вони швидко зрозуміли, що український, як й інші народи, необхідно тримати в рамках колишньої імперії. Й. Сталін писав у газеті «Правда» від 10 жовтня 1920 р., що центральна Росія не може довго триматися без допомоги окраїн, що дають багато сировини, палива, харчових продуктів... [7, с. 20]. Саме через це і через бажання придушити опір України більшовики організували загально відомі інтервенцію, «червоний терор», військовий комунізм, розкуркулення і колективізацію, знищення релігії тощо.

Співставлення партійних документів свідчить про те, що справжнім організатором голодної смерті мільйонів українців були партійні органи, керовані ЦК ленінсько-сталінської партії. У 1933 р., коли число померлих від голоду сягнуло мільйони, секретар ЦК КП(б)У Мендель Хатаєвич констатував: «...між селянами і нашою владою точиться жорстока боротьба. Це боротьба на смерть. Цей рік став випробуванням нашої сили і їхньої витривалості. Голод довів їм, хто тут господар. Він коштував мільйони життів, але колгоспна система існуватиме завжди. Ми виграли війну!» $[8,21]$.

Стає очевидним, що Голодомор 1932 - 1933 рр. був спричинений не природними явищами, а спланований керівництвом радянської держави. Внаслідок спланованого голодомору в ті роки загинуло, як свідчать дані різних досліджень, 7-8 млн людей $[6,18]$.

ХІІ з'їзд КП(б)У в січні 1934 р. визнав особливу роль ЦК у цій справі. Наголошувалось, що «винятково сприятливі умови для досягнення найшвидшого перелому на селі» $[8,21]$ відіграла промова товариша Й. Сталіна на січневому Пленумі ЦК і ЦВК ВКП(б) та на з'їзді колгоспників-ударників, а також «Закон про хлібоздачу», створення політвідділів радгоспів і МТС. Відзначалось, що під керівництвом ЦК КП(б)У розгромлено націоналістичні контрреволюційні організації, 
які намагались відірвати Україну від Радянського Союзу, «мобілізовано всю партійну організацію на боротьбу з українським націоналізмом головною небезпекою на Україні» [8, с. 21]. I як наслідок - знищення мільйонів українців.

Правляча партійна верхівка в СРСР побоювалася розростання опору радянській владі, особливо в національних районах. Зрозуміло, що невдоволення насильницькою колективізацією в Україні наростало. Про це, зокрема, оперативний наказ ДПУ УРСР від 13 лютого 1933 р. «Про чергові завдання агентурно-оперативної роботи органів ДПУ УРСР, де наголошувалось: «... організований саботаж хлібозаготівель..., організовані масові крадіжки в колгоспах і радгоспах, терор на найбільш стійких, витриманих комуністів і активістів села; перекинення на Україну восени 1932 р. десятків петлюрівських комісарів, поширення контрреволюційних листівок, дають підстави говорити про існування в Україні організованого контрреволюційного повстанського підпілля, зв'язаного із закордоном... Ми зіткнулись з єдиним, скрупульозне розробленим, планом організації збройного повстання на Україні до весни 1933 р. 3 метою повалення Радянської влади і встановлення капіталістичної держави, так званої «української незалежної республіки»« [9, арк. 28].

Не виключенням з числа терористичних дій щодо населення України став й голод 1946-1947 pp. I хоча у ті повоєнні роки у сільському господарстві досить сильно відчувалась нестача чоловічих робочих рук та явною була посуха, все ж головною причиною голоду знову стала політика радянської влади, зокрема, все та ж, хлібозаготівельна кампанія. Для іii посилення в березні 1947 р. в Україну Й. Сталін прислав Л. Кагановича, якого затвердили першим секретарем ЦК КП(б)У. Вилучений хліб, як і в 1932-1933 рр., експортувався за кордон. Його вивозили до країн Центральної та Західної Свропи - Польщу, Чехословаччину, Румунію, Болгарію, Німеччину, Францію та ін. Це робилося, в першу чергу, задля збереження політико-військового впливу у Європі та підтримки прокомуністичних режимів країн так званої «народної демократії» $[10,42]$. Протягом 1946 - 1947 рр. з України було вивезено 2,5 млн. тон зерна, а кількість жертв Голодомору 1946-1947 pp. подають різні: одні дослідники називають 1,2 млн., інші - близько 1 млн. $[11$, с. 78]. Водночас це була підготовлена сталінським режимом помста за бажання українців створити власну державу у роки війни 1941-1945 pр. та діяльність ОУН і УПА.

Більшовицька колективістська доктрина ведення господарювання призвела до катастрофічного порушення традиційних господарських зв'язків, до загальної дезорганізації виробництва. Українські селяни 
збройно протидіяли цій політиці. Терор голодом став дієвим і кінцевим заходом в їх упокоренні. Голодомори в Україні - це цілеспрямована економічна і політична політика більшовиків проти українських селян. Знищення мільйонів українських селян водночас призвело до різкої зміни демографічної ситуації в Україні, яка відчувається й нині.

\section{Література:}

1. Щербатюк В.М. Боротьба селян України проти більшовицької агресії та режиму 1917-1923 років (За матеріалами Державного архіву Київської області і Галузевого архіву Міністерства оборони України). Вісник Черкаського університету. Серія Історичні науки. Черкаси. 2008. Вип. 133-134. С. 114-120.

2. Щербатюк В.М. Тактика більшовиків щодо захоплення влади в українському селі. Визвольний шлях. 2002. № 8. С. 38-47.

3. Ленін В.І. Нова економічна політика і завдання політосвіт. Повне зібрання творів (ПЗТ). Т. 44 (червень 1921 - березень 1922). К.: Вид-во політ. літ-ри України, 1974. С. 147-166.

4. Ленин В.И. Заметки о мерах борьбы с голодом и об усилении хозяйственной работы. ПСС. Т. 44. (июнь 1921 - март 1922). М.: Изд-во полит. лит-ры, 1970. С. 67-68.

5. Ленин В.И. Телеграмма комвойсками М.В. Фрунзе, К.А. Авксентьевскому, А.М. Постникову, всем ЗК и ЗКУ Украины, командармам 4, 6 и 1 Конной Армии, комвойсками Киевского округа А.И. Егорову 1921 г. ПСС. Т. 52. (письма, ноябрь 1920 - июнь 1921). М. Изд-во полит. лит-ры. 1970. С. 300-301.

6. Кузьминець О.В., Сокур В.В., Сокур Ю.В. Більшовицькосталінські голодомори мовою документів. К.: «МП Леся». 2013. 53 с.

7. Сокур В.В., Сокур Ю.В. Голодомори мовою документів. К. Освіта України. 2017. $118 \mathrm{c.}$

8. Сокур В.В., Сокур Ю.В. Голодомори мовою документів і свідчень. 2-ге вид. доп. та перероб. К. ФОП Маслаков. 2018. 123 с.

9. Архів МВС України. Ф. 46, оп. 1, спр. 1 а, 28 арк.

10. Щербатюк В.М. Голод як засіб насильницького впровадження більшовицької політики в українському селі. Гілея (науковий вісник): Збірник наукових праџь. К. 2014. Вип. 83 (№ 4). С. 38-45.

11. Кондратюк К.К. Голод 1946-1947 pp. в Україні: сучасні інтерпретації істориків . Вісник Львівської комериійної академії. Львів. 2010. Вип. 9. С. 74-80. 